\title{
Bullying and Negotiated Identities: Perspectives of 7th and 8th Grade Girls
}

Camilla Forsberg

The self-archived postprint version of this journal article is available at Linköping University Institutional Repository (DiVA):

http:/ / urn.kb.se/ resolve?urn=urn:nbn:se:liu:diva-141125

N.B.: When citing this work, cite the original publication.

Forsberg, C., (2017), Bullying and Negotiated Identities: Perspectives of 7th and 8th Grade Girls, Children \& society, 31(5), 414-426. https:// doi.org/ 10.1111/ chso.12212

Original publication available at:

https:/ / doi.org/ 10.1111/ chso.12212

Copyright: Wiley (24 months)

http:// eu.wiley.com/WileyCDA/ 


\section{Author Details}

Bullying and Negotiated Identities: Perspectives of 7th and 8th Grade Girls

Corresponding author: Camilla Forsberg

Phone: 4613285892

e-mail: camilla.forsberg@liu.se,

Address: Department of Behavioral Sciences and Learning, Linköping

University, SE-58183 Linköping, SWEDEN

Camilla Forsberg is a postdoctoral researcher at the Department of Behavioral Sciences and Learning whose research focuses on students perspectives on bullying. 


\section{Bullying and Negotiated Identities: Perspectives of 7th and 8th Grade Girls}

The aim of this study is to explore 40 Swedish 7th and 8th grade girls' perspectives on bullying by listening to how they discuss and understand bullying. Pair and group interviews were conducted and analyzed using grounded theory. Symbolic interactionism was used as a theoretical perspective focusing on social processes and interaction. The participants constructed bullying an identity process involving gendered identities, victim identities and socially-valuable identities where bullying was located within a gendered order. These identities were negotiated with the concept self-confidence, where the girls both aligned with and distanced themselves from the gendered order.

Keywords: bullying, girls, identity, gender, grounded theory

Bullying is usually defined as repeated and intentional acts in which there is a perceived power imbalance between those involved (Olweus, 1993), and takes on different expressions: (a) physical (hits, kicks) (b) verbal (degrading comments, nicknames), or (c) indirect (social exclusion, gossip, rumors) (Borntrager and others, 2009; Olweus, 1993). Indirect bullying has been associated with children's social organization where manipulation and exclusion practices occur (Adler \& Adler, 1995; Besag, 2006; Eder, 1985; Svahn and Evaldsson, 2011). These dynamics of organizing friendships are found among both genders (Adler and Adler, 1995; Goodwin, 2002). Girls have been found to use direct acts (Philips, 2003), but a gendered pattern has also been established where boys tend to be more involved in direct bullying and girls tend to be involved in indirect bullying (Vaillancourt and others, 2010). Children themselves associate indirect bullying with girls and physical bullying with boys (Giles and Heyman, 2005, Gini and Pozzoli, 2009), but indirect acts are sometimes not defined as bullying or seen as less harmful (Forsberg and others, 2014).

Bullying amongst girls has been examined from feminist, poststructural perspectives (Davies, 1989) where normative (hetero)sexual and gendered discourses of femininity construct subjectivities affecting girls' bullying acts and identities (Currie and others, 2007; Ringrose, 2008; Ringrose and Renold, 2009). Ringrose (2008) states that dynamics of normative power structures have been overlooked in the educational discourse. With this theoretical orientation, girls' bullying has been described as a sexualized, gendered issue (Jennifer, 2013) in which girls' appearance plays a crucial role (Besag, 2006; Owens and others, 2000) and heteronormative positioning regulates girls' perceived attractiveness and popularity (Duncan, 2004; Duncan and Owens, 2011, Renold, 2005). Furthermore, popularity has been found to structure young peoples' peer groupings (Adler and Alder, 1995; Eder, 1995). Fewer studies have taken an explorative approach to girls' understanding of bullying, but their experiences are important (Ringrose, 2008). Owens and others (2000) used a vignette to study girls' subjective perspectives and their explanations for engaging in indirect bullying. Their findings showed that girls adopted indirect behaviors due to (a) boredom, (b) striving for acceptance, (c) friendship and membership processes, and (d) jealousy and self-protection. Besag (2006) found similar reasons among the girls in her study. Duncan (2004) adopted the same vignette and found that girls' relationships were constructed around popularity and sexuality, where close 
friendships were crucial and gossiping could increase popularity. Popularity itself was an indicator of who was popular among boys or not. Jamal and others (2015) recently explored girls' perspectives in the context of school bullying and gender and revealed that traditional gender and sexual discourses structure identities and girls' positioning towards bullying. However, this study did not merely focus on bullying. Overall, gender differences have been examined and contested in previous research, but few have examined girls' perspectives using an explorative approach. The aim of this study was to take such an approach towards girls' subjective perspectives of bullying by listening closely to how they discuss and understand bullying. This might add important insights to the processes the girls themselves associate with bullying.

\section{Methods}

This study is based on semi-structured pair and group interviews (4 pairs and 6 groups) with 40 Swedish 7th and 8th grade girls (13-15 years old) from three different schools from three neighborhoods. This age range was chosen to explore both their present and previous experiences of bullying, whereas pair and group interviews could be useful for exploring shared perspectives and identities (Jamal and others, 2015). Consent letters were distributed and collected from students and guardians prior to the interviews. All participants were informed about my interest in understanding their perspectives on bullying. As part of the consent letter, the participants were asked to select whom they wanted to be interviewed with in order to place them in a familiar setting while discussing such a sensitive issue. This might also change the power dynamics from the adult researcher to the participating children (Corsaro, 2011; Hennessy and Heary, 2005). Throughout the research process it has been important to reflect on the possible power dynamics between researcher and participants. The sociology of childhood therefore influenced research methodology (Corsaro, 2011), where the participants were treated as expert commentators on their social worlds and a non-judgmental and open approach for learning about their perspectives guided the research process (Corsaro, 2011). All interviews took place with only me present at their own schools and in assigned rooms with closed doors. These interviews addressed their perspectives on bullying and were open to what the participants wanted to discuss. Probing questions were actively used to further elaborate on their perspectives. The interview protocol was also revised during the data collection process to further explore their perspectives; this method is considered theoretical sampling (Charmaz, 2014). The semi-structured interviews lasted approximately 60 minutes. Approval from the Regional Ethical Review Board was obtained prior to all data collection. All interviews were audiorecorded and transcribed by the author. All names used are pseudonyms.

Constructivist grounded theory guided both the data analysis and data collection methods (Charmaz, 2014). This approach has its foundation in symbolic interactionism from which the girls' perspectives are understood as constructed through social interaction where a set of assumptions about the world are formed and used when defining and approaching the world as active interpretative actors (Blumer, 1969; Mead, 1934). Furthermore, the researcher is viewed as a co-constructor of the data and adopts an interpretative framework where multiple worlds are assumed. Using grounded theory involves shifting between data collection and three different levels of analyses (initial, focused and theoretical coding; Charmaz, 2014). Firstly, I constructed initial codes by coding data line by line and then compared these codes with each other. Secondly, during the focused coding the most frequent initial codes were used to synthesize the main concerns of the participants. These codes were later 
conceptualized into concepts with explicit definitions. Thirdly, when entering theoretical coding theoretical concepts were incorporated to construct an analytical theory from the concepts constructed.

\section{Bullying and negotiated identities}

From a symbolic interactionist perspective, the interpretation of the participants' perspectives addressed that bullying was constructed as an identity processes (Mead, 1934) located in a gendered order. Three main identities were constructed: (a) the gendered identities, (b) the victim identities, and (c) the socially-valuable identities. The gendered order was defined in the way they used the concept self-confidence, a concept which was a crucial part in the girls perspectives on bullying. The intersection of bullying and a gendered order might also be an example of an intersection of bullying and gendered harassment (cf., Meyer, 2014). The girls highlighted such an intersection when they discussed how gendered expectations (Butler, 1990) were expected from them. Two types of gendered expectations were expressed in their discussions: gendered agency expectations (e.g., using indirect bullying, perform social care, not stand up) and expectations concerning girls' bodies (e.g., fitting in to appearance norms). These gendered expectations were constructed as regulating their agency, affecting their self-confidence and bullying practices.

The participants negotiated these identities by positioning themselves and others in relation to these identities with the concept self-confidence where they negotiated who was and who was not self-confident. In order to understand these negotiations the theoretical perspective negotiated order (Strauss, 1978) was incorporated. This perspective emphasizes how social order is negotiated and ongoing, but actors are constrained by social structures while negotiating. Furthermore, it reveals dynamic and ongoing processes and constraints in a social context and the social structures that form these negotiated processes. The participants' perspectives seemed to be constrained by a gendered order that identified both self-confidence and fitting in as being crucial, but the combination of the two was difficult to achieve. The participants therefore constructed undesirable identity positions for girls but in their negotiations of these identities the participants also engaged in face saving practices (Goffman, 1967). Face work refers to interactions where the goal is to (re) construct more desirable identity positions to save face and is visible both in how the girls positioned others in more undesirable positions and in their statements of how to navigate in their social worlds. In this way the participants negotiated the meaning of femininity and gender and both aligned with, and resisted, the gendered order (e.g., Renold, 2005) and constructed bullying as gendered.

\section{The gendered identities}

Gendered identities were constructed where a positioning of bullying acts were used to dichotomize the type of bullying engaged in and experienced. Bullying was described as (a) indirect bullying from girls (e.g., gossip, dirty looks, cyberbullying, exclusion), and (b) direct bullying by boys (e.g., verbal, physical).

Manda: Girls are, well you've probably heard this, girls talk about people behind their backs and boys talk face-to-face 
Desi: Boys are more direct

Interviewer: I'm curious, how come it's like that?

Manda: Well, girls are cowards. No, but. I don't know actually.

Desi: I know some who've sent mean text messages, and then in school they act as if everything is ok, nothing has happened, and as soon as they come home they start sending mean text messages because you don't dare to say it out loud. But you get just as upset when someone is sending text messages (Group of three participants, grade 7).

These distinctions were assumed to be common knowledge, "well you have probably heard this" and "girls are". Girls and indirect bullying were described as weak and cowardly, while boys and direct bullying was daring and straightforward. Through these discussions, girls' indirect bullying techniques were conceptualized as inferior to boys'. Their positioning of girls indirect bullying could be an example of internalized sexism (Bearmen and others, 2009) where women view themselves as less powerful compared to men. However, this less favorable portrayal of girls was also contested when positioning girls' indirect bullying as affecting the victim, being emotional, caring and as thinking before acting. Boys bullying was described as straightforward but not socially adjusted. In this way the girls negotiated the negative label of girls' bullying and engaged in face work to construct a more favorable position (Goffman, 1967). However, they also discussed how a gendered order existed that affected girls' self-confidence, their agency, and made them favor indirect bullying.

Nea: Girls have less self-confidence than boys.

Sian: I think girls care more, compared to boys.

Nea: About others.

Leanne: If I just stood up and said what I think, then, my other friends would turn against me. You fear that..You want to keep your social position.

(Group of seven participants, grade 7).

This lower level of self-confidence was said to arise from gendered agency expectations (e.g., performing caring actions, not stand up) and appearance expectations concerning girls' bodies.

Interviewer: You have said "cowardly” several times now. Where does that

come from?

Paula: I don't know.

Allie: Self-confidence I think.

Jenny: Insecurity.

Paula: And some, if you're insecure some might think that you're cocky.

Allie: But you might just want to fit in.

Paula: But you get bullied instead.

Interviewer: Where does this insecurity come from?

Paula: You might not look like everyone else or...

Allie: You don't have a nice looking body, like a model.

Jenny: Or you might be different, like with your clothes.

Paula: Maybe you don't own expensive brand name clothes.

Jenny: And then you become like that.

(Group of six participants, grade 8).

Their positioning of insecurity as interlinked with appearance expectations could be an example of how girls are positioned as victims of a gendered order where not fitting in might make them insecure. The participants discussed the importance of aligning with these expectations in order to fit in and not become bullied. 
Nevertheless, by doing so some could perceive this behavior as acting "cocky”, which could position the person as a victim. Insecurity arising from low self-confidence could therefore evolve into being a bully or being bullied. While this could be an example of internalized sexism (Bearmen and others, 2009), their positioning could also be recognized as social exclusion anxiety (Søndergaard, 2012), where it is important to fit in, in order not to become excluded. This involves fitting in with these gendered expectations. Their fear of exclusion was also embedded in earlier experiences of being excluded from girls' friendships. The participants revealed that this fear had evoked a process in which they had been preoccupied with securing friendships through social control as friendships protected their social position and secured inclusion. These processes were again said to occur because of insecurity, low self-confidence and gendered expectations.

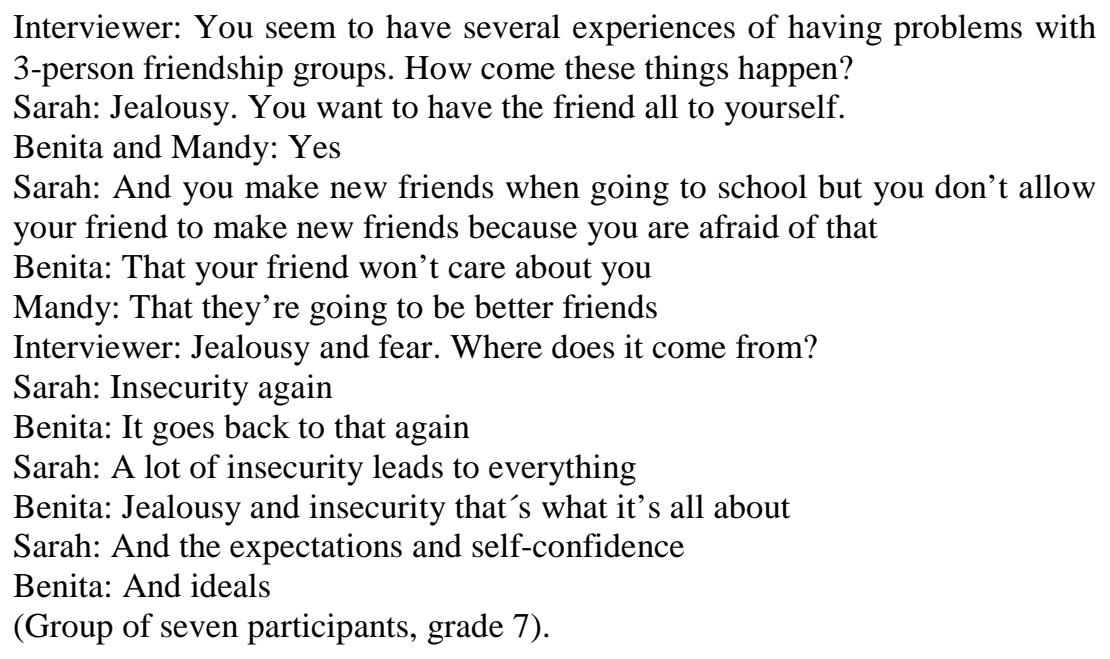

However, exclusion from close friendships was positioned in the past, while bullying involving appearance was common today (e.g. "When you were younger you excluded each other, and all of a sudden it's all about appearance”, Josy, group of three participants, grade 8). Either way, the type of bullying girls experienced and engaged in all emanated from the same causes: fear of not fitting in, jealousy and insecurity, where challenging gendered expectations contained the risk of being excluded and bullied.

\section{The victim identities}

Another main focus among the girls was victim identities. Victims were those who were bullied and were portrayed as not fitting in. This could be an example of the “odd student repertoire” (Teräsahjo and Salmivalli, 2003), used among students as an explanation for bullying (Teräsahjo and Salmivalli, 2003; Thornberg, 2015a). Being a victim was an undesirable position and they were made responsible for taking on this identity by allowing others to bully them, by defining actions as bullying or by succumbing to gendered expectations to avoid bullying. However, remember that the participants positioned girls as victims in the previous section, when they described how their use of indirect bullying occurred because of lower self-confidence due to the gendered order. Girls were also positioned as becoming victims more easily as they were described as emotional and easier to offend (e.g., "Girls are more easily offended. They take it personally”, Nea, Group of seven participants, grade 7) but not all girls were positioned in this way. This was apparent when the target was described 
as having the choice to adapt to appearance expectations (e.g., "All girls aren't insecure but we make ourselves insecure by having to look a certain way to get friends and boys”, Loreen, Group of 7 participants, grade 7). In this way some girls were positioned as making themselves insecure. This revealed different social positions where targeted girls were made responsible for succumbing to appearance expectations and for becoming affected by bullying. Though, in order to resist bullying and appearance expectations a girl needed high levels of self-confidence because low self-confidence was connected to being a victim.

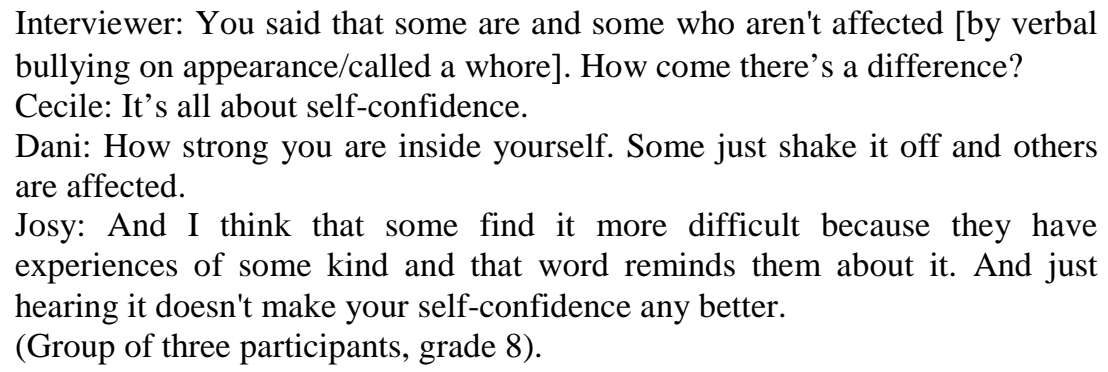

Furthermore, different incidents could be interpreted in different ways because of earlier victimization experiences where a victim identity could be evoked. Incidents could also be ignored if the person had a high self-confidence (e.g., "I think that it comes back to self-confidence, you just need to ignore these things a little," Hedda, pair interview, grade 8). Self-confidence functioned as a resource for positioning who was a victim and who was not, where some girls were positioned with more selfconfidence because they could shake off all kinds of bullying. The participants also positioned themselves as more self-confident and not as victims, as they recurrently spoke of 'others' as victims and as responsible for this identity.

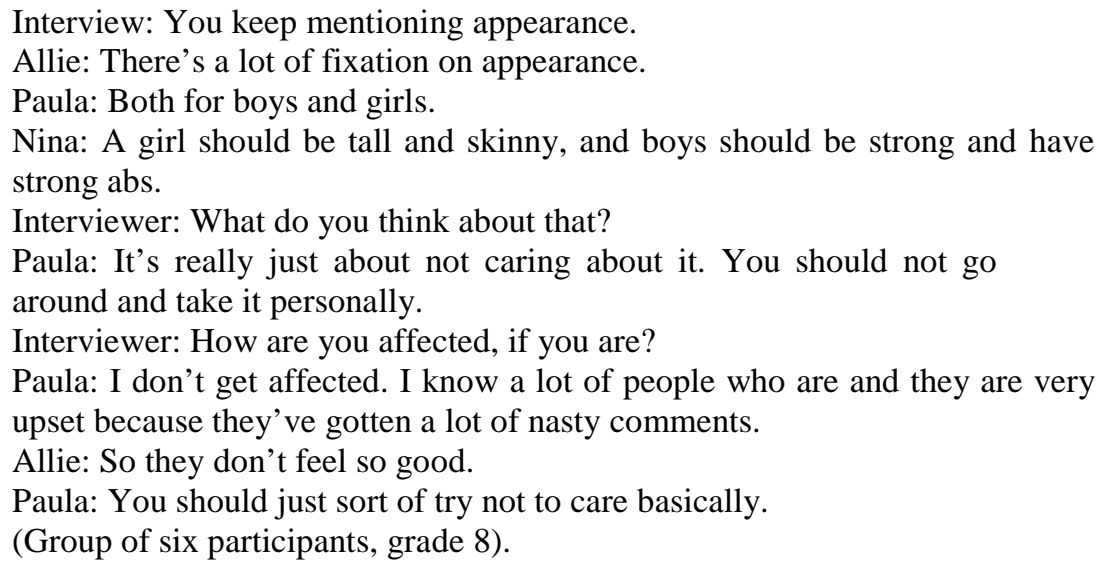

The participants reported that they themselves were only a little affected by appearance expectations and bullying regardless of 'appearance fixation'. The victim identity was also positioned to others 'I know a lot of people who are affected', but Paula was not affected herself. This might be one way for Paula to position herself as someone not receiving "nasty comments" and as a non-victim. Positioning others as victims and more affected might be recognized as a self-protection strategy to appear to be emotionally unaffected, a form of social shielding (Thornberg and others, 2013). This is an example of negotiating a more self-confident position by engaging in face work (Goffman, 1967) in order to construct a more favorable position. However, since gendered expectations were everywhere, all the girls could potentially be 
positioned as targets and victims. This evoked a need to appear less affected to avoid social ridicule to save face by interpreting incidents as jokes and as being part of a normal social life.

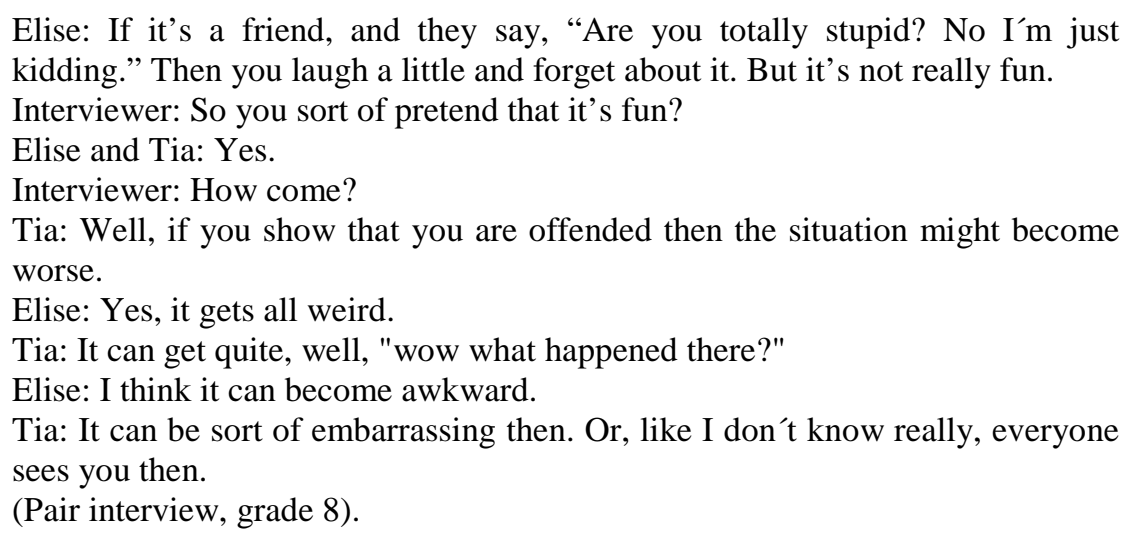

According to the participants reports the risk of social ridicule made it difficult to stand up and easier to pretend it was fun. Such an action is in contradiction to the importance of standing up and being self-confident and is rather associated with a victim identity. Only some girls were positioned as able to stand up for themselves, those who were self-confident and challenged agency expectations, but not appearance expectations.

Benita: Most of the time those who don't fit in become targets.

Sarah: Those who aren't like everyone else.

Mandy: Those who don't fulfill the social expectations enough or don't give in

to them enough.

Benita: Those who don't dare to stand up, who let others harass them.

Mandy: Those who don't have any self-confidence as well.

Joanne: And dyed hair.

(Group of seven participants, grade 7).

Adjusting to appearance expectations might be beneficial to increasing social status in a context that values girls' appearance (Bearmen and others, 2009, Renold, 2005) where girls' popularity has been associated with perceived attractiveness (Duncan, 2004; Duncan and Owens, 2011). This was associated with a victim identity because succumbing to either gendered expectations or bullying was positioned as an example of low self-confidence.

\section{The socially-valuable identities}

Throughout the participants' discussions, socially-valuable identities were negotiated around the concept of self-confidence. Socially-valuable identities seemed possible to increase and to occupy. A recurrent pattern was to position others as less sociallyvaluable, less self-confident and as victims. In the previous section, victims were defined as not fitting in, having low self-confidence and as not adapting/adapting too much to gendered expectations. Conversely, they were also positioned as brave and daring.

Manda: Since all of them don't dress like us, they look alike and dare to be brave and not like everyone else

Desi: But I think the tragic part is that they dress different and act different compared to everyone else and if you want to hang out with those who are 
different, the others might think if I'm with her then my friends might think I'm totally stupid or something

Desi: It's really like that

Manda: It's the tragic truth. You have to say that it is (Group of three participants, grade 7).

These transgressors were positioned as social outcasts, which created barriers for friendships as their social status could transmit. This identified how friendships were associated with peer pressure. Face work was evident when they positioned these brave transgressors as more possible victims, less desirable to hang out with and as deviant. The participants also positioned themselves as more desirable and as having a socially-valuable identity when performing according to gendered appearance expectations. This also revealed how others might be excluded in order to gain a socially-valuable identity themselves and by saying that the "tragic truth" required them to not become friends with these transgressors. Friendships were crucial because it said something about the persons social status, offered protection against bullying and boosted self-confidence (e.g., "Because if I have my friends, like I do now, then there's really not much that they [the bullies] can do, even if there is more than one of them." Sarah, group of seven participants in grade 7). Friendships also made it possible to challenge gendered agency expectations.

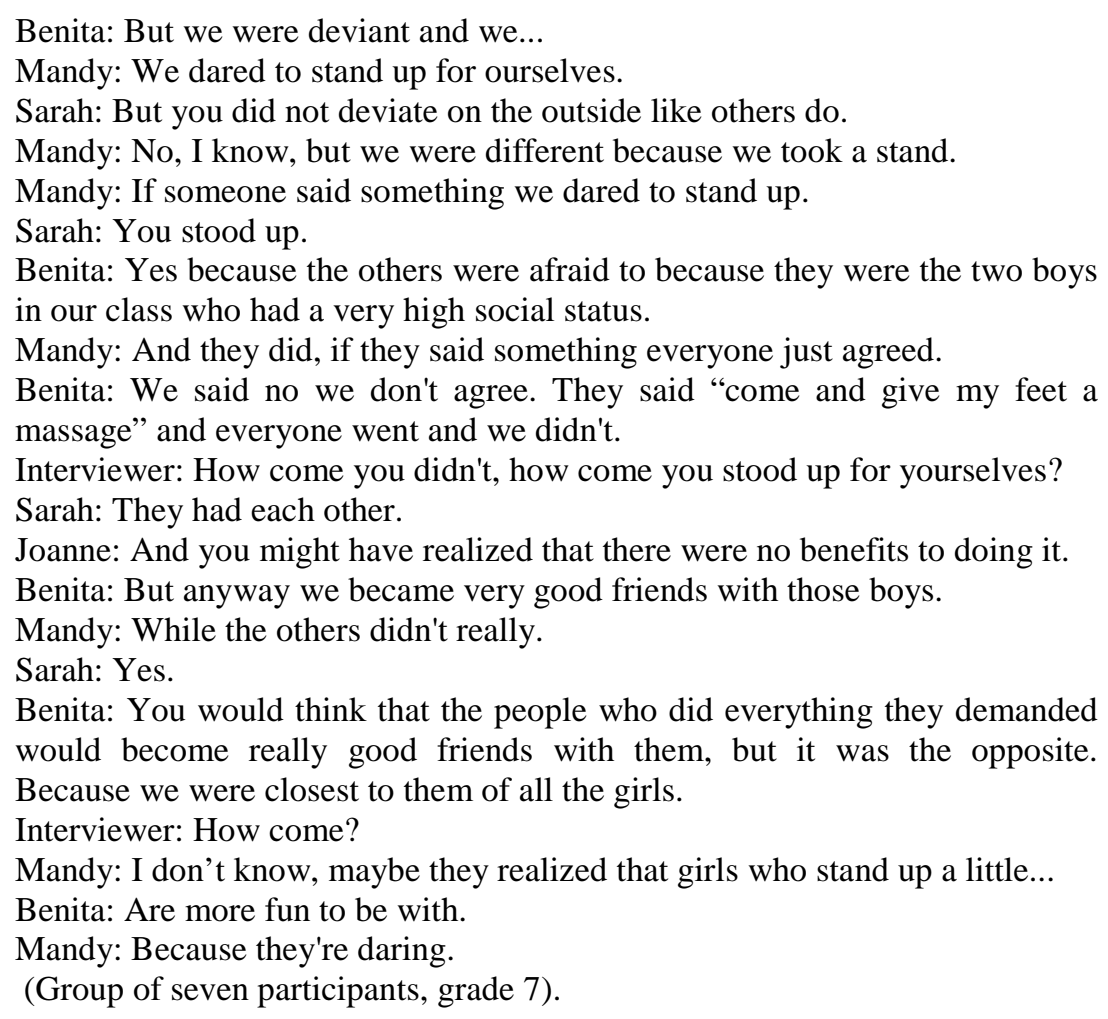

They were socially sanctioned because they challenged agency expectations when they stood up but did not deviate on "the outside". In this way they were positioned as more desirable when being defined as fitting in to appearance expectations. Their socially-valuable identity increased when they became daring like the boys. Boys functioned as a reflection of girls' social status where gender and heteronormative power relations constructed a socially-valuable femininity (Currie and others, 2006; Duncan and Owens, 2011; Ringrose, 2008). Girls' socially-valuable identities related 


\title{
Camilla Forsberg
}

to fitting in to appearance expectations and acting to gain social recognition in order to be popular among the boys. This could reinforce bullying.

Jill: You want to put other girls down to show the boys that you dare to do this Interviewer: How come you want to show that to the boys?

Laura: You want to be popular among boys. And be the best looking girl in school.

(Pair interview, grade 7).

Additionally, bullying could also increase someone's socially-valuable identity and self-confidence because the others wanted to be friends with the bully to avoid becoming victims of bullying themselves.

\author{
Sarah: People want to hang out with the bully not be bullied themselves \\ Joanne: And the bullies become more popular and self-confident \\ Sarah: And the victim gets less social status \\ Joanne: And then others don't want to hang out with the victim \\ (Group of seven participants, grade 7)
}

This is an example of a face saving practice. At the same time bullying was positioned as wrong and driven by insecurity (e.g., "Even if you're insecure you shouldn't degrade anyone to make that person feel bad about herself. They only do it to feel better about themselves.” Jill, Pair interview, grade 7). A socially-valuable identity could also be reached through feminist resistance (e.g., Renold, 2005) against appearance expectations. This was possible through a strong friendship where boys and the media were made responsible for appearance expectations.

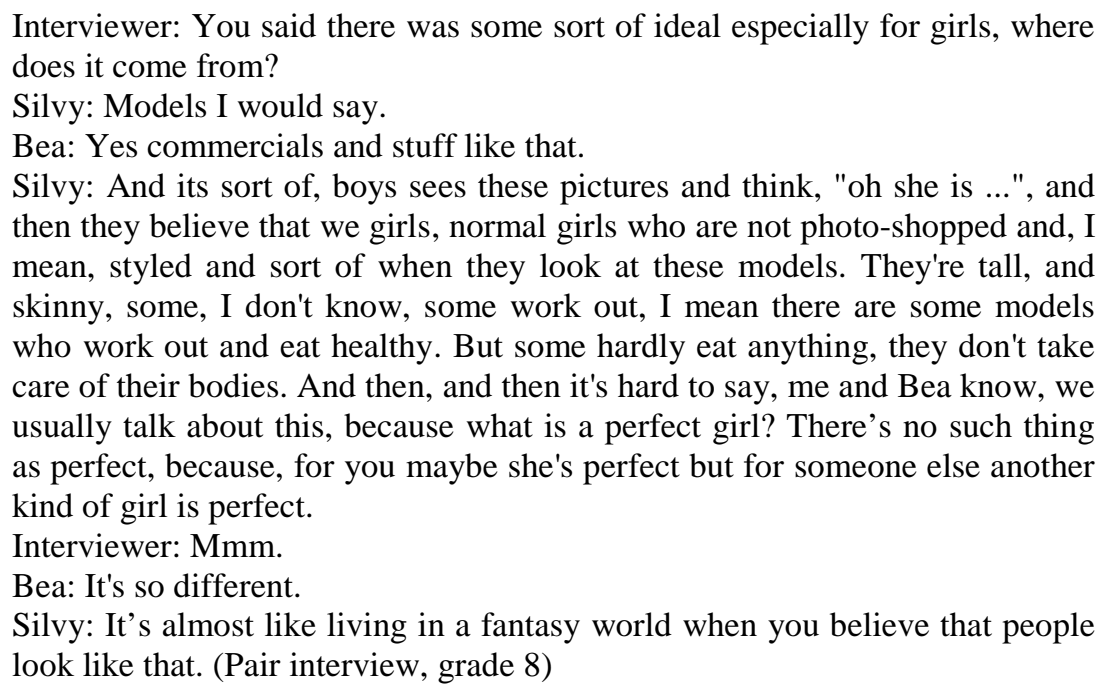

Their friendship involved "usually talk[ing] about this" where they constructed a criticism against appearance expectations and externalized the responsibility. These face saving practices deconstructed an unhealthy femininity and constructed boys as "living in a fantasy world". Their argument might open up for new constructions of socially-valuable femininities, a less socially-valuable position for boys and girls as non-victims. At the same time they constructed new norms when talking about "normal girls like us". 


\section{Conclusion}

Bullying could be understood as an identity process (Mead, 1934; Thornberg, 2015a) and three main identities were of importance in the participants' understandings of bullying (i.e. gendered identities, victim identities and socially-valuable identities). It appeared to be important to have a socially-valuable identity, which was intersected with self-confidence or manifestations of the same. However, all of these identities were located within a gendered order that addressed agency expectations (e.g., type of bullying, not stand up) and appearance expectations that affected the girls' selfconfidence because they could be bullied if they did not align with the gendered order or aligned too much. Especially appearance expectations seemed crucial and most difficult to resist. These gendered expectations might reveal that bullying intersects with gendered harassment (cf., Meyer, 2014).

The participants positioned themselves and others in relation to these identities and the gendered order by positioning themselves and others as more or less selfconfident. Self-confidence protected against bullying and said something about a person's socially-valuable identity, but was negotiated against this gendered order where the combination of a socially-valuable identity and self-confidence seemed impossible. It was crucial to correctly navigate the social landscape, but others (e.g., boys, friends) functioned as reflections of their identities as generalized others (Mead, 1934), where shared values and identity constructions were displayed. This created a dilemma where the participants either had to adjust to gendered expectations to fit in, or not care but be at risk of not fitting in. Either way they could be positioned as a victim. Girls had to fit in to the gendered order to have a socially-valuable identity, high self-confidence and secure inclusion. This revealed how they could exclude or bully others to secure their own position (cf., Haavind, 2014) and by interpreting a situation as normal social life rather than challenging the gendered order. This evoked social exclusion anxiety (Søndergaard, 2012) where it was important to not lose face (Goffman, 1967) and instead manifest self-confidence. In this way, challenging agency expectations (e.g., stand up) but not appearance expectations could increase girls' socially-valuable identity and self-confidence. This indicates that bullying includes normative power structures (Ringrose, 2008), where gendered norms construct girls' friendships and bullying and girls are caught in different identity positionings and identity struggles (Jamal and others, 2015; Ringrose, 2008).

The participants aligned with the gendered order and constructed masculinity as more valued then femininity. This was illustrated by (a) labeling indirect bullying negatively, (b) connecting appearance expectations, low self-confidence and indirect bullying with femininity and agency. Positioning girls in a negative manner and as responsible for the gendered order might be recognized as internalized sexism (Bearmen and others, 2009). However, the gendered order was also negotiated when the participants constructed more favorable positions by engaging in face work when (a) positioning indirect bullying experiences in the past, (b) labeling indirect bullying as caring, (c) labeling others as targets/victims and as responsible for this position and by (d) negotiating gendered appearance expectations by externalizing the responsibility to boys or the media.

While the interview context might have contributed to the importance of appearing self-confident by negotiating these identities and engaging in face work (e.g., Jamal and others, 2015, Svahn and Evaldsson, 2011), girls' bullying and less socially-valuable identities were located within a gendered order. Bullying was constructed as a gendered phenomenon where normative identity constructions emerge and affects the girls' social relationships in school and perspectives on 
bullying. The struggle to fit in to these identity constructions can affect whether girls report or define incidents as bullying or engage in bullying. It is therefore important to consider how bullying is part of broader social processes (e.g., Schott, 2014) and include a focus on identity processes and gendered norms (cf., Meyer, 2014).

\section{References}

Adler, PA, Adler, P. 1995. Dynamics of inclusion and exclusion in preadolescent cliques. Social Psychology Quarterly, 145-162.

Bearman, S, Korobov, N, Thorne, A. 2009. The fabric of internalized sexism. Journal of Integrated Social Sciences 1: 10-47.

Besag, V. 2006. Understanding girls' friendships, fights and feuds: A practical approach to girls' bullying. McGraw-Hill Education (UK).

Blumer, H. 1969. Symbolic interactionism: perspective and method. University of California Press: Berkeley, CA.

Borntrager, C, Davis, J.L, Bernstein, A, Gorman, H. 2009. A Cross-National Perspective on Bullying. Child youth care forum 38: 121-134.

Butler, J. (1990). Gender trouble: feminism and the subversion of identity. New York: Routledge.

Charmaz, K. 2014. Constructing grounded theory. Sage: London.

Corsaro, WA. 2011. The sociology of childhood, 3nd edn. Thousand Oaks: Pine Forge Press.

Currie, DH, Kelly, DM, Pomerantz, S. 2007. 'The power to squash people': understanding girls’ relational aggression. British Journal of Sociology of Education 28: 23-37.

Davies, B. 1989. The discursive production of the male/female dualism in school settings. Oxford Review of Education 15: 229-241.

Duncan, N. 2004. It's important to be nice, but it's nicer to be important: Girls, popularity and sexual competition. Sex education 4: 137-152.

Duncan, N, Owens, L. 2011. Bullying, social power and heteronormativity: girls' constructions of popularity. Children \& Society 25: 306-316.

Eder, D. 1985. The cycle of popularity: Interpersonal relations among female adolescents. Sociology of education, 154-165.

Forsberg, C, Thornberg, R, Samuelsson, M. 2014. Bystanders to bullying: Fourth- to seventh-grade students' perspectives on their reactions. Research Papers in Education 29: 557-576

Giles, JW, Heyman, GD. 2005. Young Children's Beliefs About the Relationship Between Gender and Aggressive Behavior. Child Development 76: 107-121

Gini, G, Pozzoli, T. (2009). "Gender roles and bullying: Behavior and motives in the peer context”. In Handbook on Gender Roles: Conflicts, Attitudes and Behaviors. Urlich, JH and Cosell, B.T.(ed.). Nova Science Publishers; 93-121.

Goodwin, MH. 2002. Exclusion in girls' peer groups: Ethnographic analysis of language practices on the playground. Human development 45: 392-415.

Goffman, E. (1967). Interaction ritual: essays in face-to-face behavior. Chicago: Aldine.

Haavind, H. (2014). "Who does he think he is? making new friends and leaving others behind- on the path from childhood to youth". In Schott, RM., \& Søndergaard, D.M. (Eds.). School Bullying: New Theories in Context (pp.129184). Cambridge: Cambridge University Press. 
Hennessy, E, Heary, C. 2005. Exploring children's views through focus groups. Researching children's experience: Approaches and methods, 236-252.

Jamal, F, Bonell, C, Harden, A, Lorenc, T. (2015). The social ecology of girls' bullying practices:: exploratory research in two London schools. Sociology of health \& illness 37: 731-744

Jennifer, D. 2013. "Girls and indirect aggression”. In Bullying: Experiences and discourses of sexuality and gender. Rivers, I, Duncan, N. (ed). London: Routledge; 45-59.

Mead, GH. 1934. Mind, self and society: from the standpoint of a social behaviorist. Chicago: University of Chicago Press.

Meyer, E. (2014). "New solutions for bullying and harassment: a post-structural, feminist approach”. In Schott, RM., \& Søndergaard, D.M. (Eds.). School Bullying: New Theories in Context (pp.209-240). Cambridge: Cambridge University Press.

Olweus, D. 1993. Bullying at School: what we know and what we can do. Oxford: Blackwell

Owens, L, Shute, R, Slee, P. 2000. “Guess what I just heard!”: Indirect aggression among teenage girls in Australia. Aggressive behavior 26: 67-83.

Renold, E. 2005. Girls, boys and junior sexualities: exploring children's gender and sexual relations in the primary school. London: Routledge

Ringrose J. 2008. 'Just be friends': exposing the limits of educational bully discourses for understanding teen girls' heterosexualized friendships and conflicts. British Journal of Sociology of Education 29: 509-522.

Ringrose, J, Renold, R. 2009. Normative cruelties and gender deviants: The performative effects of bully discourses for girls and boys in school. British Educational Research Journal 4, 1-24.

Schott, RM. (2014). "The social concept of bullying: Philosophical reflections on definitions.” ”. InSchott, RM., \& Søndergaard, DM. (Eds.). School Bullying: New Theories in Context (pp. 21-46). Cambridge: Cambridge University Press.

Søndergaard, DM. (2012). Bullying and social exclusion anxiety in schools. British Journal of Sociology of Education 33: 355-372

Strauss, AL. 1978. Negotiations: varieties, contexts, processes, and social order. San Francisco: Jossey-Bass

Svahn, J, Evaldsson, AC. 2011. 'You could just ignore me': Situating peer exclusion within the contingencies of girls' everyday interactional practices. Childhood 18: 491-508.

Teräsahjo, T, Salmivalli, C. 2003. “'She Is Not Actually Bullied.’’ The Discourse of Harassment in Student Groups. Aggressive Behaviour 29: 134-154.

Thornberg, R, Halldin, K, Bolmsjö, N, Petersson, A. 2013. Victimising of school bullying: A grounded theory. Research Papers in Education 28: 309-332.

Thornberg, R. 2015a. School bullying as a collective action: Stigma processes and identity struggling. Children \& Society 29: 310-320.

Vaillancourt, T, Brittain, H, Bennett, L, Arnocky, S, McDougall, P, Hymel, S, Cunningham, L. 2010. Places to avoid: Population-based study of student reports of unsafe and high bullying areas at school. Canadian Journal of School Psychology 25; 40-54. 